\title{
De migrante a "interno": uma leitura sociológica do processo de desvinculação social e psíquica
}

Pedro de Andrade Calil Jabur

Curso: Doutorado em Sociologia

Data da defesa: 3 de outubro de 2008

Orientador: Prof. Dr. Brasilmar Ferreira Nunes

\section{Resumo}

O presente estudo pretende, por meio de uma discussão teórica aliada a uma pesquisa de campo, reconstituir a trajetória de vida de indivíduos que migraram para Brasília e, posteriormente, apresentaram sintomas psíquicos graves, geralmente, de cunho psicótico, passando, a partir daí, a uma condição de internos em uma instituição psiquiátrica. Primeiramente, a natureza do processo migratório, tanto no sentido histórico e econômico quanto, principalmente, no sentido individual, social e psíquico, é analisada como forma de contextualizar a discussão a respeito da trajetória de vida desse indivíduo migrante. A observação do relato de vida desses indivíduos implica, primeiramente, a formulação de um conjunto de 
desenvolvimento teórico que discutirá, mediante o estabelecimento da relação clássica entre indivíduo e sociedade, o processo de formação, construção e manutenção de uma identidade social, de uma biografia social. A base desse conjunto perpassa a idéia de socialização, referência clássica da sociologia, quanto às condições como o indivíduo forma as diversas e contínuas referências sociais que o cercam e, ao mesmo tempo, é formado por elas. A fim de ampliar o entendimento desse processo de formação do sujeito social, do próprio migrante, o paradigma da dádiva aprofunda essa idéia de constituição social a partir da idéia da importância do estabelecimento e da manutenção de vínculos não só concretamente sociais, mas também simbolicamente afetivos e, por isso, constitutivos do próprio ser humano. A possibilidade de interpretação dessa dinâmica de vida requer, necessariamente, um diálogo constante entre essa perspectiva sociológica e um entendimento interno - a partir de uma ótica psicanalítica - da formação desse indivíduo como forma de investigação de um significado amplo da noção de desequilíbrio mental, tanto no sentido social, como também no sentido psíquico. A apresentação dos dados e dos relatos de vida desses pacientes psiquiátricos forma a segunda parte desta pesquisa e tem o intuito de estabelecer o diálogo entre a pesquisa realizada e o espectro teórico formulado. O conjunto da pesquisa serve, justamente, como uma espécie de amplificador da discussão iniciada, demonstrando o intuito não de demarcar uma posição efetiva e simples de causa e efeito entre a migração e o desequilíbrio mental, mas de interpretar o sentido social e psíquico que esses dois fenômenos representam na vida desses indivíduos.

Palavras-chave: processo de migração; migrante; instituição psiquiátrica; desvinculação social; desvinculação psíquica; paciente psiquiátrico; dádiva; dom; socialização; paradigmas sociológicos; relações sociais e simbólicas. 